\title{
Orthodox-Pluralized
}

\section{Nurturing the Culture of Dialogue}

\section{A Macedonian Experience}

\author{
Gjoko Gjorgjevski \\ Professor, Faculty of Orthodox Theology "St. Clement of Ohrid", Ss. Cyril and \\ Methodius University, Skopje, North Macedonia \\ gjoko.gjorgjevski@pbf.edu.mk
}

\begin{abstract}
The aim of this paper is to describe the relations between the religious communities in the Republic of North Macedonia. This paper will examine the history of each of the most numerous traditional religious communities in the country, the history of the dialogue between them and its present situation, the communication and mutual influences, as well as the attempts to overcome disagreements and misunderstandings. It is an overview of the most important activities of the dialogues and challenges in relation to the events and changes in the country.
\end{abstract}

\section{Keywords}

interreligious dialogue - orthodox - Muslim - Macedonia

The Republic of North Macedonia lies in the southern part of Europe's Balkan Peninsula. The landlocked, mountainous country is bordered to the north by Serbia and Kosovo, to the east by Bulgaria, to the south by Greece, and to the 
west by Albania. The total land area of the country is (around) 25,710 square kilometers.

The cultural mosaic called Macedonia is special because of its deep religious and national diversity. The last census in 2002 counted a population of 2.022 million inhabitants. ${ }^{1}$ According to the census, Macedonians constituted the largest ethnic group in Macedonia with $64.17 \%$, and the second largest group was the Albanians, with $25.17 \%$. More than two thirds of the inhabitants (64.8\%) - mainly Macedonians and the small Serbian and Vlachs minorities are officially Eastern Orthodox Christians. About 674.0oo Albanians, Turks, Roma and Macedonian Muslims together make up the country's Muslim population (33.3\%). Macedonia has the fifth highest proportion of Muslims in Europe.

The country is one of the successor states of former Yugoslavia and declared independence in 1991. A European Community Arbitration Committee was appointed and, after reviewing the cases of ex-Yugoslav countries, it declared that "only Slovenia and Macedonia met EC criteria for recognition, including those related to human rights." ${ }^{2}$ But, while Slovenia and Croatia were recognized by the most important EC member states in December 1991 and by the USA in April 1992, Macedonia remained unrecognized by most states at the time, as a result of Greek objections to Macedonia's name and state symbols. ${ }^{3}$ From the start, the independent State recognized all the national minorities and guaranteed them legal equality - politically, economically and socially. Its protection of their rights went beyond the requirements of both the UN and the European Union charter and its policies were more liberal and tolerant than those of other multi-ethnic states in Eastern Europe, contrasted sharply with non-recognition of Macedonians in the neighboring Balkan states. ${ }^{4}$

\subsection{Controversies on the Legal Status of the Albanian Minority}

Ethnic Albanians were represented in parliament as early as 1990 and have belonged to the governing coalitions since 1992, but they constantly insisted on their demands to be a constituent people of the State. It is important to

1 The provisions of the Ohrid agreement to elevate any minority language if the minority in question is above $20 \%$ of the population of any municipality into a co-official language for that municipality has created friction within the government, and between officials of different political and ethnic interests, resulting in the indefinite postponement of the census which started in 2011.

2 Ramet, The Macedonian Enigma, p. 215.

3 Ramet/Listhaug/Simkus, Civic and Uncivic Values in Macedonia, p. 3.

4 Rossos, Macedonia and the Macedonians, p. 278. 
underline that all governments since the independence of the State included an Albanian party with significant representatives and ministries. However, as a consequence of mutual distrust, for much of the year 2001 Macedonia was in a state of low-level civil war. Inter-religious and inter-ethnic relations have significantly improved after the eight months of armed clashes between the ethnic Albanian rebels of the National Liberation Army $(\mathrm{UCK})^{5}$ and government forces. ${ }^{6}$ The Macedonian-Albanian ethnic conflict also put the potential role of religion for the resolution of conflict situations on the agenda, as well as the need for cooperation between different religious communities. Tense negotiations under strong pressure by Western governments, including the USA, with the so called "Ohrid Framework Agreement" resulted in a revised constitution and a shift toward greater pluralism. ${ }^{7}$

With the "Law on the Use of Languages" from 2018, the Albanian language and alphabet were regarded as official in the Republic of North Macedonia. The Law, stipulating the Albanian language as the second official language in the whole territory of Macedonia, was promoted by the actual government, promoted as a policy adopted for promotion of the use of all non-majority ethnic communities' languages in Macedonia, while the opposition accused the government of adopting a law which lacks larger public support, not being evidence-based, being unconstitutional and harming the status of the Macedonian language and identity. The opposition parties assessed the law as unnecessary because the 2008 Law had already assured the official use of the Albanian language at a local level, along with the use of the smaller national minorities, in those local units where national minorities make up more

5 In January 2000, Albanian nationalists from Macedonia formed the Ushtria Qlirimtare Kombetare ne Malesine e Tetoves - UCK (NMET). Effectively a branch of the Kosovo UCK, it was commanded by Ali Ahmeti; from about 200 fighters it expanded to some 3,00o by August 2001, operating in the Black Mountains at Sipkovica village north of Tetovo. Six battalion-sized 'brigades' were led by ex-UCK and UCPмв fighters and each contained several 'battalions' or companies. There was also an independent unit of 150 Mujahedin from Afghanistan, Bosnia and Turkey. On 27 September 2001 the UCK (NMET) officially disbanded, but many fighters joined the splinter Albanian National Army (AKSH), formed in 1999 and operating in Kosovo and Macedonia until October 2003. See Zaloga/Volstad, The Yugoslav Wars, pp. 53 et seq.

6 Claiming to fight for greater rights for Albanians in Macedonia, the rebels seized nearby territory and attacked police and military forces. The insurgency spread through parts of northern and western Macedonia during the first half of 2001. As fighting intensified and tension grew throughout the country, by the early summer there were fears of a full-scale civil war. See Rossos, Macedonia and the Macedonians, p. 280.

7 Mojzes, From Crisis to Post-crisis in Macedonia, p. 5. 
than $20 \%$ of the population. ${ }^{8}$ The Venice Commission in the "Draft Opinion on the Law on the Use of Languages" expressed a strong criticism of the Law on Languages and it recommended a detailed study of the reasons behind the 2008 law change and the reasons for the shortcomings in its implementation. ${ }^{9}$

\subsection{Controversies on the Official National Nomenclature}

As a result of an ongoing dispute with Greece over the use of its name, Macedonia was admitted to membership of the United Nations in 1993 under the provisional description as the former Yugoslav Republic of Macedonia, ${ }^{10}$

8 Rizankoska, Explaining Public Support. Official languages within the local selfgovernment according to this law could be languages used by $20 \%$ of citizens living in the relevant local government and languages that make up less than $20 \%$ and could also use their language as official if the municipal council adopts such a decision. In 30 out of 81 municipalities, together with the City of Skopje, the Albanian language was official at the level of those municipalities, while Turkish, Serbian, Vlach, Romani and Bosniac were used according to the same rules in a smaller number of municipalities. See also Treneska-Deskoska, Accommodating Multilingualism in Macedonia, p. 64; Bliznakovski, Normativna ramka za jazicnite prava.

9 The Venice Commission conveys doubts on whether this Law "can be a valid reason to justify the use of a shortened procedure", taking in consideration the information that "the Law was prepared as part of a coalition agreement between two political parties (SDSM and DUI) without a proper analysis of the shortcomings of the 2008 Language Law and without consultation with the representatives of the smaller ethnic communities". In the conclusion, it is stated that "the Commission finds it difficult to understand why the preparation of the draft law was not preceded by an analysis of the causes of the reported inconsistencies (financial capacity, qualified human resources, unwillingness of the employees, absence of interest in the non-majority communities for rights following from the law, etc.), and by an impact assessment of the future law in terms of budget and human resources to be mobilized for a full implementation. As stated in the Venice Commission's Rule of Law Checklist, "[o]bstacles to the effective implementation of the law can occur not only due to the illegal or negligent action of authorities, but also because the quality of legislation makes it difficult to implement. Therefore, assessing whether the law is implementable in practice before adopting it $[\ldots]$ is very important." See Council of Europe, CDL-AD (2016) oo7, Rule of Law Checklist, §54.

10 "The deep roots of this dispute can be traced back a century, or at least as far as the Greek civil war and the beginning of the Cold War, and the declaration of independence in 1991 disturbed long sleeping ghosts. Incapable of dealing with the major conflict in former Yugoslavia, the UN rushed to prevent and resolve at least one (potential) clash. In spite of the fact that Macedonia met all requirements for membership in accordance to Article 4 of the UN Charter, an additional requirement was imposed with regard to the name. In short, Macedonia's admission to the UN was in breach of the Charter. Ever since, the state has been named 'the former Yugoslav Republic of Macedonia' - a bizarre reference to a deceased state. The first ever UN preventive deployment mission was later established on the ground to monitor a negative peace." Vankovska, $A$ diplomatic fairytale or geopolitics as usual, pp. 113-134. 
a term that is also used by international organizations such as the European Union, the Council of Europe, and NaTo. ${ }^{11}$ The "Prespa agreement"12 would see the country change its name to the Republic of North Macedonia. It was signed between the Macedonian and Greek foreign ministers in the presence of their respective prime ministers, Zoran Zaev and Alexis Tsipras, on 17 June 2018 as a way of resolving the long-standing name dispute between their countries. The agreement stipulates that the Republic of Macedonia would change its constitutional name to the Republic of North Macedonia in exchange for accession to both the European Union (EU) and the North Atlantic Treaty Organization (NATO) with the permission of the latter. ${ }^{13}$ After that, there were protests against the agreement in Macedonia and in Greece. The international community has unanimously defined the treaty as a historic and positive step towards achieving peace and stability in the Balkans. ${ }^{14}$ Parliament approved of the name change on 19 October and the vote to amend the constitution and change the name of the country passed on 11 January 2019 in favor of the amendment. The amendment entered into force following the ratification of the Prespa agreement by the Greek Parliament. According to some experts, contrary to international expectations, the Prespa agreement is an accord that is deeply unpopular in both countries. It has been said that "it will not improve relations between the two countries"15 and that "the day that was applauded as historic marked the beginning of a long list of violations of the rule of law and democratic principles in order to push forward the name change and the geopolitical agenda", ${ }^{16}$ having in mind that from the beginning "the talks leading to the Agreement were of a coercive nature designed to produce a short-term possible gain at the cost of increasing regional instability". ${ }^{17}$

It seems important to underline that the Prespa Agreement is happening during the procedure on the "Law on the Use of Languages" and therefore the connection between them is not unexpected. The majority of ethnic Macedonians have not supported the agreement, neither the law. A referendum

11 "Macedonia" in Worldmark Encyclopedia of Religious Practices, pp. 333-343.

12 The Agreement itself is named after a lake shared between Macedonia, Greece and Albania.

13 The country is already close to both NATO and the EU. Macedonia has been sending troops on missions to Iraq and Afghanistan (without any parliamentary discussion though). The only limitation is that it cannot vote at the North Atlantic Council. The EU is Macedonia's largest trading partner, accounting for $60 \%$ of the country's exports and $48 \%$ of its imports. See Waters, The Truth about the Prespa Agreement.

14 Waters, The Truth about the Prespa Agreement.

15 Waters, The Truth about the Prespa Agreement.

16 Vankovska, A Diplomatic Fairytale or Geopolitics as Usual, p. 116.

17 Velevski, Interview with James Pettifer. 
was held on 30 September 2018, asking voters whether they supported EU and NATO membership by accepting the Prespa Agreement. The voter turnout was around $37 \%$, and thus less than the $50 \%$ threshold required to validate the result, as a consequence of the boycott of the referendum by a great part of the Macedonians.

The Prespa Agreement has deeply interfered with and also changed the internal state of affairs of the country. The nationality is "Macedonian/citizen of the Republic of North Macedonia", and the terms "Macedonia" and "Macedonian" cease to be used to refer to the previous Republic of Macedonia in any official context. As it is explained that

as a part of the deal with Greece [...] anything connected to the state, the government, the presidency, private entities and actors related to the state or activities financed by the state abroad will use the adjective North [...]. North Macedonia should also be used for all other official bodies too, for example, local municipalities and Saints Cyril and Methodius University. ${ }^{18}$

This document has the official stance that the name of the country indicates only the territory (northern part of Macedonia) and has nothing to do with the name and identity of the majority of the population, who still remain not recognized by neighbouring Greece and Bulgaria (where the Macedonian minority does not exist because it is forbidden). ${ }^{19}$ After the Prespa agreement, Bulgaria asked North Macedonia to drop claims that there is a "Macedonian" minority in Bulgaria and to stop claiming the existence of the Macedonian identity and language. ${ }^{20}$

2

\section{Multiple and Longstanding Religious Traditions of North Macedonia}

Today, Macedonia is a secular state, with a constitution that guarantees freedom of worship and prohibits discrimination on the grounds of religious affiliation. ${ }^{21}$ The Constitution of the Republic of North Macedonia from 2001

18 Government of the Republic of North Macedonia, Q\&A on Prespa Agreement.

19 Human Rights Watch/Helsinki, Denying Ethnic Identity, The Macedonians of Greece; в ВС News, Greece's Invisible Minority - the Macedonian Slavs.

20 Antonompoulos, Bulgaria Tells Skopje they must Drop Claim.

21 In the previous period, the restriction on religion in the Former Yugoslav Federation was gradually relaxed in favour of a cautious promotion of religious identities. The following 
mentions five specific religious groups: Macedonian Orthodox Church (MOC), Islamic Community of Macedonia (ICM), Catholic Church, Jewish Community and United Methodist Church. Members of other faiths have argued that this gives preferential treatment by the government to these five groups.

According to a 2012 Gallup poll, Macedonia is the most religious country in Europe and fifth in the world. ${ }^{22}$ However, the number of practicing believers is considerably lower than the number of those who declare themselves as religious. Most are baptized and married according to religious rules and respect traditional religious customs.

\subsection{Orthodox Church}

Since the first centuries, there have been Christian centers with bishop's seats: Stobi, Heraclea, Bargala, Skupi, and others. ${ }^{23}$ In the ninth century, the most prominent among the disciples of St. Cyril and Methodius, the brothers who created a Slavic alphabet, were St. Clement and St. Naum of Ohrid, who continued their missionary activities in Ohrid. St. Clement established a wellorganized school in Ohrid, where in seven years, 3.500 students were educated. Later, he was appointed bishop of the territory around the Ohrid Lake. This diocese soon grew into the Ohrid Archbishopric. This Church of Ohrid, being autocephalous, held jurisdiction over various territories during different periods, sometimes even from the Danube and Dalmatia to the Black Sea and Sicilia, but the seat was always in Ohrid, in the territory of Macedonia. Around 250 years ago, in 1767, the Ottoman administration abolished the Ohrid Archbishopric and its dioceses were given to the Constantinopolitan Patriarchate. With its abolition, the Archbishopric of Ohrid provoked a deep impact not only on the ecclesiastical, but also on the civic history of that area, because, for centuries, it was positioned between the most important institutions. This left a strong imprint on the history and the destiny of the population in the Balkans.

In the 19th century, the Ottoman Empire, under international pressure, allowed the national Orthodox churches of neighboring Bulgaria, Greece,

stages in the restrictions against religion could be outlined: (1) radical restriction of religious liberty $1945^{-1953}$, characterized by the complete separation of church and state (with abolishment of religious education ingrained in the Yugoslav constitution of 1945); (2) gradual relaxation of restrictions 1953-1965; (3) significant liberalization 1965-1971; (4) re-imposition of selective restrictions 1972-1982; (5) emergence of new opportunities for religious expression 1982-1989. See Merdjanova/Patrice, Religion as a Conversation Starter, p. 42; Mojzes, Religious Liberty in Eastern Europe and the USSR, p. 344.

22 WIN-Gallup International, Global Index of Religion and Atheism.

23 See Gjorgjevski, Macedonian Orthodox Church in the Context of Balkan and European Orthodoxy. 
and Serbia to work in various parts of Macedonia. During the Balkan Wars of 1912-1913 and during World War I, the territory of present-day Macedonia came under Bulgarian rule; after the war, in 1920, it became a part of the Kingdom of Yugoslavia wherein the renewed Serbian Orthodox Church took on the dioceses in this part of Macedonia. This state of affairs lasted until 1941, when, after the beginning of World War II, the Serbian hierarchy left Macedonia, and Bulgaria established the jurisdiction of the Bulgarian Church in the eastern part, while a small part of western Macedonia fell under the jurisdiction of the Albanian Orthodox Church. These forced changes of foreign church jurisdiction provoked a revolt among the people and the native clergy, who decided never to allow a church administration which is not domestic. In 1943, on the first liberated territory in Debarca, near Ohrid, at the Assembly held by the priests from that region, as well as at the Clergy-Laity Council held in 1945 in Skopje, a renewal of the Ohrid Archbishopric and an independent church were demanded.

At the Clergy-Laity Assembly held in Ohrid in October $195^{8}$ (attended by priests, monks, and faithful people), the Ohrid Archbishopric in the form of the Macedonian Orthodox Church was renewed and Bishop Dositej, vicar of the Serbian Patriarch, was elected as the first head of the church. The name "Macedonian Orthodox Church" was taken following the example of the other Orthodox churches. Immediately after this decision for the renewal of the Ohrid Archbishopric, the Council of the Serbian Orthodox Church, held in July 1959, concluded that the dioceses in the People's Republic of Macedonia had established an independent church and the Constitution of the Serbian Orthodox Church was no longer valid for those dioceses and for their bishops.

In the period that followed, mutual understanding was missing: the Serbian Orthodox Church insisted on an autonomous status of the Moc, while the MOC itself demanded complete independence, i.e. autocephaly. Thus, in 1967, at the Clergy-Laity Assembly in Ohrid, the attendees voted to renew the Ohrid Archbishopric as an autocephalous Macedonian Orthodox Church. However, the opposition of the Serbian Orthodox Church to the new reality officially isolated the Macedonian Orthodox Church from the other Orthodox churches. For all the subsequent efforts to gain recognition, the autocephaly of the Macedonian Church has not yet been recognized by other Orthodox churches in defense of Serbian opposition.

Therefore, the Macedonian Orthodox Church has constantly attempted to overcome this state of affairs. In the last 50 years, commissions from both churches have met many times, but after all the meetings and discussions, no solution has been reached, neither for its status, nor for its name, which 
appears to be one of the biggest obstacles from the side of the Greek Orthodox Churches.

After several meetings at the end of the 2oth and the beginning of the 21st centuries, in 2002 in the Serbian city of Nish, Macedonian and Serbian Orthodox Church officials met to discuss the status of the Macedonian Church. The Macedonian part was asked to sign an agreement that would downgrade the Macedonian Church to an autonomous body within the Serbian Orthodox Church and the Macedonian Church would be renamed the Archbishopric of Ohrid. This proposal was with unanimity rejected by the Macedonian Synod and the Macedonian people. But, one of the Bishops of Mос, Metropolitan Jovan (Vranishkovski) of Povardarie, ${ }^{24}$ has crossed over to the Serbian Orthodox Church, which has 'made use' of his leaving and has appointed him an "exarch of the Serbian Orthodox Church in Macedonia" (in that time Jovan was already accused of canonical offences and criminal activities). This act of the Serbian Orthodox Church was seen as interference also in the internal affairs of the Macedonian State and society, and as a result of that, in 2004, the Macedonian Parliament adopted a declaration that supported the Macedonian Orthodox Church, all efforts and decisions made by the Macedonian Synod, as well as its commitment to preserving its integrity, significant status, and role in the social life of the country (understood in terms of contribution of the Church as a defender of external ecclesiastical jurisdictions which are seen as foreign territorial claims).

The Serbian Church in Macedonia ("Orthodox Archbishopric of Ohrid" $\mathrm{OAO}$ ) is still not registered as religious community and still does not have a legal status. ${ }^{25}$ On other side, in January 2016, the Religious Community of Orthodox

24 On 24 June 1998 Jovan (Vraniskovski) was elected as a vicar of the Diocese of Prespa and Pelagonija. On 8 March 2000 he became Administrator of the Diocese of Bregalnica. A few months later, on 15 November 2000, he was removed from the previous diocese because of financial irregularities and appointed as Administrator for the Diocese of Povardarie. In June 2002 he left the Macedonian Orthodox Church. In 2004 he was sentenced to 18 months of imprisonment. In 2006 he was again tried and sentenced for 2 years, on charges of embezzlement of a donation of 57 , ooo Euro and, later, on charges of embezzling 324,00o Euro from the diocese funds while he was a bishop with the Moc. He was sentenced to five and a half years in jail in 2012, but was released in January 2015. UNHCR, U.S. Department of State Annual Report on International Religious Freedom for 2006 - Macedonia; www.orthochristian.com, Archbishop Jovan Of Ohrid To Be Released From Prison On January 19.

25 According to the present Law on the Legal Status of a Church, Religious Community and a Religious Group, art. 10: "The name and official insignia of each new church, religious community and religious group shall be different from the names and official insignia of already registered churches, religious communities and religious groups". Legislation Online, Law on the Legal Status of Church. 
Albanians was founded and officially recognized by the State. ${ }^{26}$ In order to fulfil the condition for registration, the Community declares the doctrine to be different of the Orthodox teaching. The religious community neither has had clergy, services nor any activity since the foundation.

In November 2009, the Macedonian Orthodox Church at its regular Clergy-Laity Assembly, changed the Constitution and added to its name the title "Archbishopric of Ohrid" with the church being officially titled "Macedonian Orthodox Church - Archbishopric of Ohrid".

The scholars and experts openly remember the role of foreign ecclesiastical jurisdiction in the Macedonian territory for the purpose of implementation of a national-state policy. Therefore, an experience of suffering by the political misuse of the church for the purpose of denationalization and assimilation in the past provides a comprehensible reason why almost all Macedonian people are rejecting the forced imposition of foreign ecclesiastical jurisdiction. After the recognition of the Autocephalous Church in Ukraine, which was established by the Ecumenical Patriarchate in January 2019, there are expectations also regarding the Orthodox Church in North Macedonia. ${ }^{27}$

In the period previous to the Prespa Agreement, Moc had no official position towards the topic, but clerics of the MOc, the Metropolitan Petar and Metropolitan Agatangel among them, have actively participated in the protests held against the country's name change. ${ }^{28} \mathrm{~A}$ few days later, Metropolitan Petar was detained at the airport. The Financial Police Directorate issued a statement saying that it is a subject which is in a pre-trial procedure, and they are not able to share the information publicly. ${ }^{29}$

26 The initiator and founder of this religious community is the university professor Branislav Sinadinovski, who, at the age of 60 , publicly admitted that he is of Albanian ethnicity and that so far he had not revealed his national identity. According to him, the idea for the creation of the Albanian Orthodox Community (even though only consisting of ten believers) has received great support because it is created in order to restore the identity of this community which is dispersed. Pajaziti, Albanian Orthodox Community.

27 In May 2019, Macedonia's government confirmed that the Prime Minister had sent a request for help to Patriarch Bartholomew of Constantinople. After that, the Synod of the Ecumenical Patriarchate of Constantinople said in a press release that it had considered the request of the MOC and the Macedonian Prime Minister for help in solving the Church's status under the name "Archdiocese of Ohrid", and was willing to act. The Synod said it had decided to act on "the request of the breakaway church in Skopje, supported by a letter from the Prime Minister of FYROM [Macedonia's provisional UN reference], Zoran Zaev, for the Ecumenical Patriarchate to take the initiative to return the Church within the [Orthodox] canonical framework under the name Archdiocese of Ohrid".

28 Pajaziti, Church Clergy Protests Against the Name Change.

29 Castbox, Bishop Petar was Detained. 
Regarding the internal unresolved problems, MOC is claiming a lack of understanding of the government for a proper solution and adequate application of religious education in schools and for delaying the process of denationalization. According to the ecclesiastical authorities, half of the requests have not yet received any answer or have received a negative answer. ${ }^{30}$

\subsection{Islamic Community}

Taking into consideration that the territory of the present Republic of North Macedonia was part of the Ottoman Empire for 500 years, the Turkish presence was significant, and many Macedonian towns, including Skopje, experienced a significant Muslim presence until the Balkan Wars of 1912-1913. Under Ottoman rule, the organization of the religious life of Muslims was under the jurisdiction of the Sheyhul-Islam (mufti, or head of the Muslim clergy) in Istanbul; after the Balkan Wars and World War I, it came under the Reis Ulema (mufti), with headquarters in Sarajevo, Bosnia and Herzegovina. Outside of the Muslim community, Sufi (mystical) orders such as the Rifai, Halveti, Melami, and especially the unorthodox Bektashi dervishes (members of a Muslim religious order known for acts of ecstatic devotion), who were strongly influenced by the Alevis, had to survive in a state of half legality, while many tekkes (monasteries) were closed.

Since the Republic of Macedonia gained independence, the Islamic community continues to act as an independent religious community, organizing its religious life in the wakfs (land endowed specifically for religious purposes) and its administrative-financial activities. Regarding the realization of the Islamic practices, the Islamic community applies the Hanafi school of law. The Islamic community theoretically represents all Muslims in Macedonia, yet the members of the Bektashi order do not recognize its authority and grapple for their recognition as a separate community. ${ }^{31}$ According to the census in 2002, the Islamic community has around 660,00o believers (Albanians 509,083, Turks 77,959, Roma 53,879, Macedonians 2,553, Bosniacs 17,018).

Since Macedonia's independence, the Islamic community was faced with internal problems, but also with inter-religious conflict situations. ${ }^{32}$ Dissatisfied

30 Only the Diocese of Skopje is waiting for properties in building for more than 11,000 square meters. There are a lot of prolonged lawsuits without any decision, as that of the Monastery of Matka (Ilievska-Pachemska, Posledna bitka za planinarskiot) or for the property of 2770 hectares of the Monastery of St. Naum in Ohrid, denationalized after the Second World War (Golabovksi, Prodolzuva bitkata za vracanje na crkovnite imoti).

31 Merdjanova/Brodeur, Religion as a Conversation Starter, p. 58.

32 In 2010 representatives of the Islamic Community of Macedonia (ICM) suspended Imam Ramadan Ramadani of Isa Bey mosque for spreading radical Islam. The ICM 
with the lack of fulfillment of their demands by the government, the Islamic community boycotted the last World Conference on Inter-Religious and Inter-Civilisation Dialogue held in Skopje in 2013 and in Bitola in 2016.

In March 2019, the Islamic Religious Community (IRC) in Macedonia headed by Reis Ul Ulema Hadzi Sulejman Efendi Rexhepi went in conflict with the current government and the Prime Minister Zoran Zaev. According to sources, the reason for this conflict is the great promises Zaev gave but never fulfilled. They tried to resolve the conflicting views about the denationalization of religious buildings belonging to the IRC, warning them that they were forced to inform the faithful in 700 mosques on the country's discrimination against the IRC and its members. ${ }^{33}$ The government publicly released the response addressed

claimed that Isa Bey and three other mosques in Skopje had fallen under the control of radical Wahhabists and later called on "the government, ethnic Albanian political parties, state institutions, and all foreign diplomats in Macedonia to support the Islamic community and take measures against these radical structures" (quoted in the U.S. State Department's International Religious Freedom Report in 2011). Ramadani has denied these allegations and has accused the leadership of the Islamic community of being corrupt. The Macedonian authorities had taken action against a Wahhabi community in the Albanian-populated village of Brodec in November 2007, apprehending 13 of the Wahhabis and taking possession of a huge arsenal of diverse weaponry. This proved to be only a minor setback for the local Wahhabis, however, and, having lost five mosques to the Wahhabis between April and September 2010, the mainstream Islamic community was reported to be increasingly alarmed by their activity. The heads of the Islamic religious community in Macedonia, appealed to the authorities "to support [the] IVZ and take appropriate measures against these radical groups whose goal is to harm [Macedonia's] image and prevent our country from entering [the] EU and NATo." See Rexhepi, as quoted in Siniša Jakov Marušić, Macedonian Muslims Seek Support Against Radicals; see Ramet, Religion and Politics in Post-Socialist Central and Southeastern Europe, p. 13. The Millennium Cross, a 216-foot- (65.8-meter-) highmemorial commemorating 2,ooo years of Christianity and situated on the top of the Vodno Mountain in Skopje, was constructed in 2002 with contributions from the Macedonian government and donations from Macedonians around the world. The Islamic community openly protested the cross, considering it a provocation of Albanians in the country. The government has also denied restitution of the Burmali mosque, demolished in the 1920s, to the Islamic community, stating that the ruling coalition's ethnic Macedonian party and the Macedonian Church could not accept a new mosque in Skopje's city center. Near the Burmali mosque is the Saint Constantine and Elena Church, which was destroyed during the Communist period. Its restoration was stopped after reactions by secular movements that do not want religious buildings in the central square of the nation's capital. A proposed new location for the church has also been debated by the Islamic community, which claims the site is on their property.

33 The incident comes as the Islamic community is involved in a dispute with the Government and demands the return of huge properties across Macedonia given to it by the Ottoman Empire and taken away after its defeat and during the Communist regime. The Reis Ul Ulema Hadzi Sulejman Efendi Rexhepi wrote a letter to the Government about the slow 
to the leadership of the Islamic Religious Community, after receiving a letter from the IRC, which according to them contains a kind of blackmail, threats and ultimatums for cases, which are being processed in the competent institutions. ${ }^{34}$ The justification is that the major part of requests of the IRS is related to the Ottoman period, while the 2000 Denationalization Law accorded the right to denationalization of property seized only after August 1944 to former owners and their successors. Among the disputed property is the Husamedin Pasha Mosque in Shtip which was nationalized in $1955 \cdot{ }^{35}$

\subsection{Catholic Church}

The Catholic Church in Macedonia falls under two institutions: the Skopje Bishopric for Latin Catholics and the Apostle Exarchate for Catholics of Byzantine Rite; both are headed by the same bishop. Catholicism of the Byzantine Rite (Unionist) attracted a small but significant part of the Orthodox Slavic population in the 19th century, though this development was primarily influenced because of the dissatisfaction of the Slavonic faithful with the Ecumenical Patriarchate of Constantinople. The Slavonic population used the threat of conversion to exert pressure over the patriarchate to accede to their demand for Slavonic priests and bishops and the use of Old Church Slavonic instead of Greek - as the liturgical language.

On 7 May 2019, Pope Francis made the first-ever papal visit to North Macedonia. In a meeting with government authorities, Francis praised North Macedonia's multiethnic and multifaith culture and said its example of being a bridge between East and West showed that peaceful coexistence can occur in

procedure for denationalization, as well as the everyday problems that the IRC had from the authorities that interfered with its work and the daily activity of maintaining religious objects that are a cultural heritage. The IRC points out that they are particularly affected by the failure to resolve the status of religious buildings in Lazec, Bitola, the Husameddin Pasha Mosque in Stip, which is registered to another religious community, for which the proceedings are still ongoing. They in the letter accuse the Government of favoring the MOC, which, according to them, was privileged in every respect. At the end of the letter, they leave a 1o-day deadline for the Government to solve the above-mentioned problems and seek urgent protection against discrimination against the IRC and citizens of the Muslim faith. Rexhepi also insisted that construction work on a towering minaret in the center of Ohrid continues despite the fact that the city council refused to approve its construction (the construction was finished without permission).

34 See Republika English, IRC at War with Zoran Zaev for Unfulfilled Promises.

35 The mosque is also known as the church of St. Elia, because it is believed to have been built on the foundations of an ancient Christian religious place. According to some narratives, Husamedin Mehmed Pasha built the mosque in the 17 th century on the foundations of a church from the 13th or 14th century that was dedicated to St. Ilija (Jovanka/Mahmut, Monuments of Islamic Culture and Civilization in Shtip). 
a country rich in diversity. Pope Francis urged the Balkans to embrace its patchwork of faiths and ethnicities during his visit to North Macedonia, where he delivered prayers and speeches that kept returning to the legacy of an illustrious Skopje native: Mother Teresa. Addressing political leaders, Francis praised the "crucible of cultures and ethnic and religious identities" in "your land, a bridge between East and West". North Macedonia's diversity, which reflects the mix of communities in the wider Western Balkan region, is a "mosaic in which every piece is essential for the uniqueness and beauty of the whole", he added. The pontiff said "unfailing respect for diversity" was key to the entire region's "increased integration with the nations of Europe". 36

\section{$2.4 \quad$ United Methodist Church}

The United Methodist Church has been present in this region since the mid18oos. The Methodist Episcopal Church and the Congregational Church sent American Protestant missionaries to Macedonia in the 19th century. They established Episcopal stations and schools in many Macedonian towns. In the early 21st century, the United Methodist Church in Macedonia had 13 churches and one center for social outreach. Boris Trajkovski (1956-2004), the second president and supreme commander of the Republic of Macedonia from 1999 to 2004, studied theology in addition to law. He became a Methodist lay minister and president of the Church Council of the Macedonian United Methodist Church.

\subsection{Jewish Community}

Jews in Macedonia - and the Balkan Peninsula in general - have a long history. Archaeological excavations in Stobi confirm the existence of a synagogue from the second through the fifth century CE. There are also records of a Jewish community in a number of cities in the Balkans before the banishment of Jews by Spain in 1492 and by Portugal in 1498. During World War II, 98\% of the Jewish population (roughly 7,200 individuals) in Macedonia were killed in the Treblinka death camp. In 1946, the community was left with only 471 members; one fourth of them had come from parts of what was then Yugoslavia. Upon the establishment of the state of Israel in 1948, a number of Jews left Macedonia to move to the new state; membership to the community has slowly fallen ever since.

36 Catholic News Agency, Pope Commends North Macedonians for Respect among Cultures. 
In 2002, pursuant to the Law on Denationalization, the government set up a Holocaust Fund. The fund is responsible for managing formerly Jewish-owned heirless property, creating a Holocaust Museum, which opened in 2011. ${ }^{37}$

\section{Inter-Religious Dialogue in the Face of Societal Change}

In the past it seems to have been lacking the broad-based inter-religious dialogue in Macedonia; generally each religious community developed alongside one another with a decent level of mutual recognition and interaction. ${ }^{38}$ However, the conflict in 2001 has changed the situation drastically. For most people in Macedonia and for many people outside the country, it came as a surprise. Despite it being unexpected, it did come, brought casualties and hundreds of thousands of displaced people. The conflict soon severely deteriorated existing inter-ethnic relations. The most visible characteristic was the ethnic component of the conflict, between the ethnic Macedonian majority and the ethnic Albanian minority in the country. The inter-faith component was not accentuated in the conflict (ethnic and linguistic issues and the question of minority and majority rights are sufficiently prominent so that religion did not surface as a major issue), but it was also used for escalating the conflict (with the attacks on churches, mosques and sacral objects). This aspect was an underlying feature since most of the ethnic Macedonians are Orthodox Christians, while almost all ethnic Albanians in Macedonia are Muslims. With the armed conflict, the communication between the churches and religious communities in Macedonia deteriorated further.

\subsection{First International Attempts towards IRD}

Inter-religious cooperation in those circumstances did not come easily and naturally. The inter-religious dialogue with the major religious communities also contributed to a change from distrust and belligerence among the Orthodox Church leadership and the Muslim clergy to the building of trust. In response to the worsening civil conflict in the country, a meeting of the

37 World Jewish Restitution Organization, WJRO North Macedonia Operations. The 2007 Compensation Agreement among the government, the Holocaust Fund, and the Jewish Community allowed for the payment of 21.1 million euros ( $\$ 24.2$ million) between June 2009 and June 2018. US Department of State, 2019 Country Reports on Human Rights Practices: North Macedonia.

38 During the Communist period, when all religious communities were being attacked, a certain degree of collaboration and mutual acceptance characterized inter-religious relations. See Mojzes, Toward a more Comprehensive Understanding of Interreligious Dialogue. 
leaders and representatives of the main religious communities in the Republic of Macedonia was organized for an international round table meeting with the international ecumenical organizations near Geneva, Switzerland, in June 2001. The meeting was arranged by the World Council of Churches with the Macedonian Centre for International Cooperation and the Conference of European Churches. The round table meeting involved senior representatives of the Macedonian Orthodox Church, the Islamic Religious Community, the Catholic Church, the United Methodist Church and the Jewish Community in Macedonia. Archbishop Anastasios of Albania, an internationally-respected head of church and ecumenical leader, was the Chairman of the meeting with the result of a joint declaration for peace. The meeting and declaration attracted considerable attention in the country, although this did not prevent continued examples of violence against religious objects. ${ }^{39}$ The World Conference on Religion and Peace brought the Orthodox Archbishop and the Reis ul Ulema to New York City, but no meetings and other dialogue initiatives took place in Macedonia itself during 2001 and the tension and suspicion between the members of the religious communities continued.

\subsection{Establishment of an Official Council for Inter-Religious Cooperation}

An important international Jewish-Christian-Muslim dialogue conference took place in Skopje, 10-14 May 2002, with the topic: "Confidence Building between the Churches and Religious Communities in Macedonia through Dialogue."40 Nearly fifty official representatives of the five Macedonian religious denominations and forty international participants met for nearly five days of intensive interaction, often with the presence of a large number of observers. At the opening session, the conference was greeted by President Boris Trajkovski and

39 "Peace is too important to be left only to the politicians [...] we firmly believe that it is the responsibility of religious communities to speak and work for peace [...] religious communities must be used as sources of healing and reconciliation," stated participants at a gathering of religious leaders representing five religious communities from Macedonia. "Our churches and religious communities are not involved in the conflict, and we strongly reject any tendency to allow ourselves to be involved and manipulated, as well as any misuse of religious symbols and language for the purposes of violence [...] We strongly believe that answers to problems should always be sought with an open and constant dialogue, based on a complete mutual respect and on the respect of the differences and the values of other religious traditions and communities. That is the only way given by the One God and there is no other way" - it was said in the joint statement. "We feel and accept the need, and agree to undertake concrete actions in this direction, individually and as churches and religious communities" (World Council of Churches, Round Table Meeting). 
the religious leaders. The Conference resulted in several concrete suggestions, and one of them was to establish the Council for Inter-Religious Cooperation. ${ }^{41}$

The Council for Inter-Religious Cooperation has now been founded 15 years ago, it was constituted by the heads of the five major religious communities listed in Macedonia's constitution. The Council has been actively working for several goals, particularly regarding topics such as the wording for a new law on religious communities, the introduction of religious education in schools, ${ }^{42}$ and the process of restitution of religious property seized during the Yugoslav Communist regime. The Macedonian religious leadership decided to work for the fostering of inter-religious dialogue at all levels, prioritizing the grassrootstop approach. The following major points of cooperation emerged: religious education, property restitution, drafting the law on religion and the inclusion of the Orthodox and Islamic theological faculties in the state university system. ${ }^{43}$ In December 2019, the Macedonian Interreligious Council asked for changes in the Constitution regarding the clarification of marriage as the union

41 See Mojzes, Orthodoxy and Islam in the Former Yugoslav Lands, pp. 797 et seq.

42 Regarding religious education in schools, the Macedonian Orthodox Church and the Islamic community have the same position, insisting on a confessional approach. The smaller religious communities (due to the objective obstacle, having an insufficient number of students for creating an independent class) prefer a history of religion. Confessional religion classes for children of Orthodox and Islamic families were introduced for the first time in 2001 only for the students in the $3^{\text {th }}$ ( $5^{\text {th }}$ ) class, and terminated in 2009, after the Macedonian Constitutional Court struck down the subject, which incited heated debates regarding the form and content of religious education in state schools. The Decision (published in "Official Gazette of the Republic of Macedonia", Decision U.no.103/2008): "The noted provisions in Article 19 and Amendment VII of the Constitution promote the freedom of confession, but at the same time establish the principle of separation of the state and the religious communities, that is, the principle of secularity. Freedom of confession, in the opinion of the Court, unavoidably contains in itself the principles that everyone is free, without anybody's influence, to determine his/her religious belief, to accept or not certain religion or to accept another religion, or not to accept any religion whatsoever, to profess or not his/her religion, to take part or not in religious sermons, etc. In this context, the state, on its part, pursuant to the principle of separation of religious communities, must maintain its neutrality and must not interfere in the issues on religion, that is, religious communities and groups, incite the determination for a certain religion or religion in general, or obstruct the expression of religion, or impose religious conformism or request implementation of religious activities as socially desirable conduct. The Court found that the noted constitutional amendment also resolves, in a principled manner, the issue about religious education (religious instruction, religious teaching) which is left to be the subject of decision and sphere of concern of religious communities and groups, within the frameworks of the freedoms to establish religious schools for these purposes." In 2010, the "Ethic in religions" (religious approach) was introduced as a one year optional course with "History of religions" (historical-sociological approach). 
of a man and a woman and that adoption is acceptable only for a traditionally married couple. ${ }^{44}$ For the Helsinki Committees for Human Rights, it was defined as "spreading hate against the LGBT community". ${ }^{45}$ The advancement or regress of the dialogue mainly depends on the two main religious communities in Macedonia, the Orthodox Church and the Islamic community. The actual circumstances have also deeply influenced the disposition of mutual cooperation. It was noted that the Macedonian Orthodox Church has been remarkably affected because of its isolation by the rest of the Orthodox world, which still refuses to recognize it officially, while the Islamic community has been struggling not only with the local impact of growing European and international islamophobia, but also with internal disputes (the contest over the Grand Mufti's post by various groups, the attempts at the infiltration of radical Islamist groups, complaints by minority Muslim groups of ethnic Macedonians, Bosniacs, Turks and Roma that the Islamic community is dominated by ethnic Albanians). This intra-religious fragility, for Orthodox Christians and Muslims alike, seems to result in greater openness and desire for inter-religious dialogue by both communities and the two communities from time to time turn into natural allies in regard to a number of issues. ${ }^{46}$

In the previous period, the Council organized several inter-religious conferences in Ohrid, Tetovo and Strumica, some kind of meeting of the priests, imams and the faithful, meetings with more spiritual than scientific atmosphere, meetings that allow for the sharing of experiences of common life together. This proves that the Council for Inter-Religious Cooperation is needed in Macedonia, and that it can contribute to the improvement of the relations between the churches and the religious communities, and also the understanding for them in the Macedonian community. ${ }^{47}$

44 Ramet, Religion and Politics in Post-Socialist Central and Southeastern Europe, p. 7. See Pravdiko, Ustavni izmeni.

45 Stankovic, Helsinskiot komitet reagira.

46 Merdjanova/Brodeur, Religion as a Conversation Starter, p. 71.

47 See Mojzes, Peacemaking through Interreligious Dialogue in Macedonia, pp. 29-34. During a survey, to the question 'Do you know that there is an inter-religious council in Macedonia', $23.2 \%$ of the Orthodox and $29.2 \%$ of the Muslims answered in the affirmative, which imposes the conclusion that greater affirmation is needed, but also greater activity of this body. To the second question 'Do you think that a more active role of this inter-religious council would increase inter-religious tolerance and prevent possible conflicts on religious grounds', $29.7 \%$ of Orthodox and $47.5 \%$ of Muslims answered in the affirmative, while $27.5 \%$ of Orthodox and $19.2 \%$ of Muslims believe that the council will not have any influence. A high $42.8 \%$ of Orthodox and 33.3\% of Muslims did not have any opinion on this issue. "Makedonija kako multikonfesionalno opstestvo - percepcii za vlijanijeto megju religijata i drzavata", p. 27. 


\subsection{Further Attempts to Implement IRD}

In April 2003, the religious communities also started with a Program for Interreligious Collaboration which lasted until 2008. The goal of the program, supported by the Macedonian Centre for International Cooperation, was to increase the level of understanding amongst the religious communities and the Macedonian public in general. ${ }^{48}$

In effect, this project was based and realized in the most part between the Faculty of Orthodox Theology and the Islamic Theological Faculty. The dialogue, which took place between religious educators and students, was definitely worthwhile and had a meaningful and effective impact.

As the aims of the program were to share experiences and inter-religious dialogue, the access to information related to the religious communities was upgraded through an educative approach, which was intended not only for the communities themselves but also for the general public. Different activities were implemented.

One of these projects was the exchange of lectures. ${ }^{49}$ Students of the theological faculties made several visits to the educational institutions (faculties and high schools) of the other religious communities. ${ }^{50}$ Apart from looking around the actual property and attending a service, the participants were given an opportunity to hear more about the basic characteristics of the hosting religious community, ${ }^{51}$ architecture of the religious buildings, the significance of the services and the like. The visitors are generally in agreement when it comes to the usefulness of the visits, since it allows for mutual introduction and communication. The inter-religious summer camps in Struga in 2004 and 2006 had significant feedback, where the participants represented their religious communities and had the chance to socialize with representatives from other religious communities. Several lectures were delivered on the topic

48 For more about the projects see Bridging Religions in Macedonia, https://mcms.mk.

49 The project consisted of lecture exchanges between the Faculties of Theology. In that way professors specialized for specific subjects of their religion from one faculty held lectures for the students of the other faculty. With the lectures, students were able to meet with the religion and teaching of the others. In the period from 2003 to 2007 , a total of 26 exchange lectures were organized, covering 590 students. The lectures incited the interest of the students; the high interest has made the classes to last two hours, instead of the planned 45 minutes.

50 Quite a few visits to religious objects and services followed; in addition to the students of the theological educational institutions and the members of the religious communities, the visits were open to interested citizens as well. Each visit was publicly advertised, thus the interested citizens could apply for participation in the visit. In the period between 2003 and 2007, a total of 20 visits was organized for $35^{\circ}$ participants.

$5^{1}$ In the period between $2003-2007$, a total of eight visits was organized for 160 students. 
of dialogue, humanism and cooperation. The aim of the project - basic skills training - was to improve the capacities of the churches and the religious communities in Macedonia through training their activists or clerics (in this case in English language and with computers). Eventually, training for 60 individuals (students, professors, activists and clerics) was delivered. The project had envisioned joint attendance at the courses, thus creating an atmosphere for bonding, especially between the students of the Faculties of Theology. ${ }^{52}$ During the last several years, this project between the Faculty of Orthodox Theology and the Islamic Theological Faculty has continued with different activities with the support of the Konrad Adenauer Foundation. ${ }^{53}$

The Bulletin of the religious communities received significant attention, publishing 800 copies in Macedonian and Albanian language. ${ }^{54}$ The aim of the publication was to give basic information about the five religious communities and both of the Theological Faculties and the cooperation between them. Once the first issue had been released, the students already showed interest in partaking in the preparation activities for the ensuing issues.

The inter-religious calendars were very useful and attractive, and included information about the most important holidays, messages from the holy books and photos depicting the most significant religious buildings of each of the five religious communities and their names. ${ }^{55}$ Several books of comparative

$5^{2}$ Several seminars and workshops also took place. Within the framework of this project, a round table under the title "The condition and the perspectives of the religious education system within the Islamic religious community" was organized. The implementation of the round table was under the patronage of the Islamic religious community in the Republic of Macedonia and was organized by the Faculty of Islamic Studies - Skopje. The round table was held on 17 May 2004 at the Holiday Inn Hotel - Skopje. There were religious workers and intellectuals from Macedonia, Albania, and Kosovo in attendance. They made significant contributions with their papers and work on the analysis of this issue and put forward ideas for the required reforms in the religious educational system. Another seminar was held on 13 September 2004 with topics that referred to important and actual questions, for example, 'What does it mean to be a believer in a modern multicultural society', nationality in apluralistic society, the relation between the state and the religious communities, why inter-religious cooperation, 'How can the Christians and the Muslims communicate and work together', etc.

53 Konrad Adenauer Stiftung, Interreligiöses Klassenzimmer; Pravoslaven Bogoslovski Fakultet, Sredba na studentite od Pravoslavniot.

54 The first edition was published in March 2004. So far, 12 editions have been released; 500 copies are published in Macedonian, 300 in Albanian, while some issues have been also translated into English.

55 Wall calendars depicting motifs from nature in Macedonian and Albanian language, desk calendars and pocket calendars. The religious communities distributed the calendars to the wider public. Thus, the public was informed about the holidays, fasting days, and the commemorative days of the churches and the religious communities. 
analysis on specific theological questions and their treatment in different religions were published; some of them were translations, and some original comparative studies. There was also a publication of an address book of the religious communities, which was foreseen to contain basic information about the registered churches and religious communities in Macedonia (office address, contact data, type and number of religious objects, educational institutions, publications and newsletters, humanitarian organizations etc.). In 2004 one Inter-Religious Info and Dialogue Centre was put into operation. A considerable amount of publications was submitted by the religious communities.

The most important event on inter-religious dialogue happened in Ohrid in October 2007, when the First World Conference on Interreligious and Intercultural Dialogue "Contribution of religion and culture to peace, mutual respect and collaboration took place". The target group included 400 participants, faith leaders and clergy from all over the world, representatives of the diplomatic and political corps, university professors, donors and representatives of the civil society sector. Local, national and international media made a wide coverage of the event. The Conference had a great public response in Macedonia and other countries as well and finished with a Declaration. The participants emphasized the significance of such assemblies at which the followers of different religions talk with love, tolerance and respect, declaring how important it is to know and to practice their religion. ${ }^{56}$

In May 2010, the Second World Conference on Inter-Religious and Inter-Civilization Dialogue took place in Ohrid under the motto "Religion and Culture - Unbreakable Chain among Nations". Participation in the Second Conference was also high with a share of two third (200) of foreign participants from 50 countries worldwide and one third (100) from the country. ${ }^{57} \mathrm{The}$ third conference was organized in Skopje 2013 and the fourth in Bitola 2016.

\section{Conclusion: On the Role of IRD in a Multicultural and Multireligious Country}

North Macedonia is a society under rapid social change. In the eyes of some the Balkans and Macedonia have perhaps misunderstood democracy. Macedonia has tried to gain a new civil orientation, but it is possible, instead of creating a civil society, to move forward into a binational society. According to other analysts, post-framework Macedonia which, instead of steadily advancing in the

56 Bridging Religions in Macedonia, https://mcms.mk.

57 unesco, World Conference on Dialogue among Religions and Civilizations. 
process of establishing internal peace and Europeanization, became an oasis of stagnation, tension, partitocracy and a model of a divided society. ${ }^{58}$ Notable attention is needed when the ethnicity (mostly) overlaps with religious affiliation, in our case Macedonians as Orthodox Christians and Albanians as Muslims. This religious aspect is extremely sensitive, because ethnic conflicts can easily be transformed into religious conflicts, which is an extremely vulnerable element for this kind of society. ${ }^{59}$ In any case, the views, statements and visions for a harmonius common society by scholars and experts from both sides are quite encouraging, particularly from the Albanian Muslim community. People from different ethnic groups should start learning how to live together. The real model that is yet to be established is the model of democratic ethos, the model of society that addresses the requests and needs of different cultural groups, i.e. the inclusive society. Extremes such as the idea that Albanians (Muslims) and Macedonians (Orthodox Christians) are two separate worlds, the presumption that the characters of these two nations do not coincide, should be replaced with a request on common ground for normal communication and the respect of differences and values of the other. ${ }^{60}$ Accepting multiculturalism anticipated with the Framework Agreement is essential, and conditio sine qua non for the future and survival of the Third Macedonia, for the transfer from "hostile co-existence" towards a normal one. ${ }^{61}$ "Macedonia as a born again identity should be built as unitas multiplex, as a single item comprised of many elements that are functionally interconnected". ${ }^{62}$

Against this background, the author is convinced that the inter-religious dialogue, "if carried out in a spirit of equality and full participation, it is capable, for the first time in the history of Macedonia to lead to greater human rights and liberties".63 In general, Macedonian citizens expect much greater activity from the religious community in the public aspect of society and they want to see the religious communities as a healthy social partner of the State.

$5^{8} \quad$ Ali Pajaziti, Culturological Studies, p. 33.

59 In the Macedonian political discourse, religion often appears as a trump card for the political parties in their agenda, especially during periods of pre-election and electoral processes. Religion and religious feeling have been involved many times in one way or another (also concerning whether the use of religious symbols and religious speech in election campaigns is a problematic practice). All of these topics in Macedonia open the dilemma of the capacity and level of secularism of the State, and, on the other hand, the capacity and ability of religious institutions to work to improve cohesive elements in society. Bozinovski/Nikolovski, Makedonija kako multikonfesionalno opstestvo, pp. 7 et seq.

6o Ali Pajaziti, Culturological Studies, p. 19.

61 Nehat Sadiku, Turbulencapolitike, p. 17.

62 Ali Pajaziti, Culturological Studies, p. 21.

63 See Bardhi, Islamic Humanism: A Foundation for Interreligious Dialogue, pp. 66-72. 
If implemented correctly, the concept of a multi-religious state can be a significant cohesive force between citizens of different religions, but in the case of misapplication or misuse and segmentation of society on a religious basis, multiconfessionalism may become a source of conflicts, even in a society like Macedonia, where there is a long tradition of coexistence between different religions.

In nuce, one has to keep in mind that his national and religious diversity existed in Macedonia even before multiculturalism as politics and theory arose. It is older than the notion of multiculturalism, which entails the contemporary notions of human rights and cultural rights. ${ }^{64}$ This gives the solid base for further development of the inter-religious and intercultural dialogue in the country. Nord Macedonia and its citizens find themselves at a peculiar moment in their history with a clear vision of a common future, searching for ways to live peacefully in this multicultural and multireligious world, looking more forward and not backward. In that way the dialogue is indispensable because "the dialogue is the only path pleasing to God. This is because God always and in many ways dialogues with us, seeking the free offering of our heart and not our forced presentation before Him. Let us offer our hearts to Him and not the hearts of others" (Bartholomew, the Ecumenical Patriarch, during the Interfaith Dialogue Assembly in Ankara in 1998). And as one of the major experts about this topic wrote: "[O]ne may dare to hope that the common desire of all Balkan communities to be 'Europe' will prevail and that efforts in that direction both locally and internationally will make not only cohabitation possible, but perhaps to be followed by reconciliation and cooperation through political negotiations and interreligious dialogue".65

\section{Biography}

Gjoko Gjorgjevski is a Professor of Old Testament at the Faculty of Orthodox Theology, "St. Clement of Ohrid" of Ss. Cyril and Methodius University in Skopje, since 2001. He received his Ph.D. in Biblical Theology form the Pontifical Gregorian University in Rome in 200o. He is currently the Dean of the Faculty of Orthodox Theology. For the past twenty years, he has been actively involved in matters of interreligious dialogue. He is the former Ambassador of the Republic of Macedonia to the Holy See from 2010 to 2014.

64 See Ivanov, Miletskiot system, pp. 67-77.

65 Mojzes, Orthodoxy and Islam in the Former Yugoslav Lands, p. 8o4. 


\section{Bibliography}

Antonompoulos, Paul: Bulgaria Tells Skopje they must Drop Claim there is 'Macedonian Language' to Join the EU, https://greekcitytimes.com/2020/o4/19/bulgaria-tellsskopje-they-must-drop-claim-there-is-a-macedonian-language-to-join-the-eu/ (date of last access: 11.09.2020).

Bardhi, Ismail: Islamic Humanism: A Foundation for Interreligious Dialogue, Interreligious Dialogue Toward Reconciliation in Macedonia and Bosnia, in:Journal for Ecumenical Studies 39 (1-2/2002), pp. 66-72.

Bridging Religions in Macedonia: Projects, https://mcms.mk/MSM/eng/projects.htm (date of last access: 11.09.2020).

в вС News: Greece's Invisible Minority - the Macedonian Slavs, https://www.bbc.com/ news/stories-47258809,published on 24.02.2019 (date of last access: 11.09.2020).

Bliznakovski, Jovan: Normativna ramka za jazicnite prava na malcinstvata vo Makedonija vo soglasnost so Ohridskiot ramkoven dogovor, Journal of European Issues Evrodijalog, Vol. 14, 2011.

Bozinovski, Vladimir/Nikolovski, Marjan: Makedonija kako multikonfesionalno opstestvo, Konrad Adenauer, Skopje, 2018, https://www.kas.de/c/document_library/ get_file?uuid=93e2a1o1-c2d 7-7896-2cfe-213ba7e4c8o4\&groupId=281657 (date of last access: 16.09 .2020$)$.

Castbox: Bishop Petar was Detained and Released by the Finance Police at the Airport in Skopje, https://castbox.fm/episode/Bishop-Petar-was-detained-and-rel eased-by-the-Finance-Police-at-the-airport-in-Skopje-Владиката-Петар-задржа н\%2С-па-пуштен\% $2 \mathrm{C}$-од-Финасиската-полиција-на-аеродромот-во-Скопј e-id84176-id73o11629? country=us, published on 04.12.2018 (date of last access: 11.09.2020).

Catholic News Agency: Pope Commends North Macedoniansfor Respect among Cultures, Ethnic Identities", https://www.catholicnewsagency.com/news/pope-commendsnorth-macedonians-for-respect-among-cultures-ethnic-identities-80457, published on 07.05.2019 (date of last access: 11.09.2020).

Council of Europe: European Commission for Democracy through Law. CDL-AD (2016) o07, Rule of Law Checklist, §54, https://www.venice.coe.int/webforms/documents/ default.aspx?pdffile=CDL-AD(2016)oo7-e (date of last access: 11.09.2020).

Denkova, Jovanka/Celik, Mahmut: Monuments of Islamic Culture and Civilization in Shtip, http://eprints.ugd.edu.mk/13205/6/Paper\%2ofor\%2oBal-Tam\%2O 2015-Denkova-Celik.pdf (no publication date given) (date of last access: 11.09.2020). Gjorgjevski, Gjoko:Macedonian Orthodox Church in the Context of Balkan and European Orthodoxy, in: Occasional Papers on Religion in Eastern Europe 37 (4/2017), Special Issue on the Fiftieth Anniversary of the Declaration of the Autocephaly of the 
Macedonian Orthodox Church, http://digitalcommons.georgefox.edu/ree/vol37/ iss4/ (date of last access: 11.09.2020).

Golabovksi, Krste: Prodolzuva bitkata za vracanje na crkovnite imoti, TVM, https://tvm. $\mathrm{mk} /$ vesti/ohrid/8959-muzej-voda-pristanishte-samo-jahti, published on o6.10.2010 (date of last access: 14.09.2020).

Government of the Republic of North Macedonia: Q\&A on Prespa Agreement, https:// vlada.mk/node/16897? ln=en-gb, published on 23.02.2019 (date of last access: 11.09.2020).

Human Rights Watch/Helsinki: Denying Ethnic Identity, the Macedonians of Greece, https://www.hrw.org/legacy/reports/pdfs/g/greece/greeceg45.pdf (date of last access: 11.09.2020).

Ilievska-Pachemska, Maja: Posledna bitka za planinarskiot dom Matka, crkvata go prezema so izvrsiteli, planinarite go baraat na sud, https://makfax.com.mk/ investigative-story, published on 06.03.2018 (date of last access: 14.09.2020).

Ivanov, Gjorge: Miletskiot system - model na religiozna tolerancija, in: Politicka Misla 8 (2004), pp. 67-77.

Konrad Adenauer Stiftung: InterreligiösesKlassenzimmer, published on 20.12.2017, https://www.kas.de/veranstaltungsberichte/detail/-/content/interreligioesesklassenzimmer-vı (date of last access: 11.09.2020).

Legislation Online: Law on the Legal Status of a Church, Religious Community and a Religious Group, 20.09.2007, Official Gazette No.113, https://www.legislationline.org/ download/id/4456/file/fYROM_Law\%2Oon\%2oReligious\%2oCommunities_2Oo7_ en.pdf (date of last access: 16.og.2020).

"Macedonia" in: Worldmark Encyclopedia of Religious Practices, Second Edition, Gale, 2013, pp. 333-343.

Marušić, Siniša Jakov: Radical Islam 'Threatens Macedonia', in: Balkan Insight (02.07.2010), https://balkaninsight.com/2010/07/o2/radical-islam-threatensmacedonia/ (date of last access: 11.09.2020).

Marušić, Siniša Jakov: Macedonian Muslims Seek Support against Radicals, Balkan Insight, http://www.balkaninsight.com/en/article/macedonian-muslims-seeksupportagainst-radicals,published on 21.09.2010 (date of last access: o6.o6.2011).

Merdjanova, Ina/Brodeur, Patrice: Religion as a Conversation Starter: Interreligious Dialogue for Peacebuilding in the Balkans (Continuum Advances in Religious Studies). London/New York, NY: Continuum, 2010.

Mojzes, Paul: Toward a more Comprehensive Understanding of Interreligious Dialogue. Rosemont College, PA, http://forel.idn.org.rs/tekstovi/clanci/Mojzes-Compr\%2O Under\%20of\%2oDialogue.pdf (date of last access: 14.09.2020).

Mojzes, Paul: Religious Liberty in Eastern Europe and the USSR: Before and After the Great Transformation. Boulder, CO, East European Monographs, 1992. 
Mojzes, Paul: From Crisis to Post-crisis in Macedonia, in: Occasional Papers on Religion in Eastern Europe 22 (4/2002), pp. 1-6.

Mojzes, Paul: Peacemaking through Interreligious Dialogue in Macedonia, in: David R. Smock (ed.): Religious Contributions to Peacemaking: When Religion Brings Peace, Not War. Washington, DC: United States Institute of Peace, 20o6, pp. 29-34.

Mojzes, Paul: Orthodoxy and Islam in the Former Yugoslav Lands, in: Teme - Časopisza Društvene Nauke, no. 4 (2007).

MUMC: World Conference of Inter-religious Dialogue (no date of publication given), https://mcms.mk/en/about-us/our-objectives/acceptance-of-culturaldiversity/709-msm203-svetska-konferencija-za-megureligiski-dijalog-2007.html (date of last access: 11.09.2020).

Official Gazette of the Republic of Macedonia: "Decision U.no.202/2008”, no.103/2008, http://ustavensud.mk/?p=12416\&lang=en, published on 15.04.2009 (date of last access: 11.09 .2020$)$.

www.orthochristian.com: Archbishop Jovan Of Ohrid To Be Released From Prison On January 19, http://orthochristian.com/76491.html, published on 13.01.2015 (date of last access: 16.o9.2020).

OSCE Yearbook 2018, https://www.nomos-elibrary.de/10.5771/9783845298283/osceyearbook-2018 (date of last access: 11.09.2020), pp. 113-134.

Pajaziti, Naser: Albanian Orthodox Community in FYRom Set Up Their Religious Communion, https://balkaneu.com/albanian-orthodox-community-fyrom-setreligious-communion/, published on 05.01.2016 (date of last access: 11.09.2020).

Pajaziti, Naser: Church Clergy Protests Against the Name Change, published on 28.02.2018, https://balkaneu.com/church-clergy-protests-against-the-namechange/?fb_comment_id=1824230150984579_183046004036159o.

Pajaziti, Ali: Culturological Studies, Education, Politics, Identity. Skopje, Dauti Foundation, 2012.

Pravdiko: Ustavni izmeni: Definiranje na brakot kako zaednica povegju maz I zena, https://www.pravdiko.mk/ustavni-izmeni-definirane-na-brakot-kako-zaednitsapomegu-mazh-i-zhena/, published on 30.04.2014 (date of last access: 11.09.2020).

Pravoslaven Bogoslovski Fakultet: Sredba na studentite od Pravoslavniot bogoslovski fakultet i Fakultetot za islamski nauki, https://pbf.edu.mk/sredba-na-studentitena-pbf-i-fakultetot-za-islamski-nauki/ (date of last access: 11.09.2020).

Ramet, Sabrina Petra: The Macedonian Enigma, in: Sabrina Petra Ramet/ Ljubiša S. Adamovich (eds.): Beyond Yugoslavia: Politics, Economics, and Culture in a Shattered Community. Boulder, CO: Westview Press, 1995, pp. 211-236.

Ramet, Sabrina Petra/Listhaug, Ola/Simkus, Albert (eds.): Civic and Uncivic Values in Macedonia. Value Transformation, Education and Media. New York, NY: Springer, 2013. 
Ramet, Sabrina Petra: Religion and Politics in Post-Socialist Central and Southeastern Europe. Challenges since 1989. London: Palgrave Millen, 2014.

Republika English: "IRC at War With Zoran Zaev for Unfulfilled Promises", https:// english.republika.mk/news/macedonia/irc-at-war-with-zoran-zaev-for-unfulfilledpromises/, published on 22.03.2019 (date of last access: 11.09.2020).

Rizankoska, Josipa: Explaining Public Support for the Law on the Use of Languages in Macedonia, in: Journal of Liberty and International Affairs 5 (1/2019), pp. 9-30.

Rossos, Andrew: Macedonia and the Macedonians, A History. Stanford, CA: Hoover Press, 2008.

Stankovic, Sinisa: Helsinshiot komitet reagira poradi sirenje na omraza kon LGBT licata, https://mk.voanews.com/a/macedonian-voa-helsinci-macedonia-112694374/ 453331.html, published on 30.12.2010 (date of last access: 11.09.2020).

Sadiku, Nehat: Turbulencapolitike. Sh. b. Shkupi, Skopje, 2004.

Treneska-Deskoska, Renata: Accommodating Multilingualism in Macedonia, in: Social Inclusion 5 (4/2017), pp. 6o-68.

TVM: Prodolzuva bitkata za vracanje na crkovnite imoti, published on o6.10.2010, https://tvm.mk/vesti/ohrid/8959-muzej-voda-pristanishte-samo-jahti (date of last access: 11.09.2O2O).

Unesco: Building Peace in the Minds of Men and Women: World Conference on Dialogue among Religions and Civilizations, Ohrid 2010, http://www.unesco.org/ new/en/unesco/events/all-events/?tx_browser_pi1\%5BshowUid\%5D=1636\&cHash =d2fcae 5478 (date of last access: 11.09.2020).

United States Institute of Peace: Special Report. What Works? Evaluating Interfaith Dialogue Programs, July 2014, https://www.usip.org/sites/default/files/sr123.pdf (date of last access: 11.09.2020).

UNHCR: U.S. Department of State Annual Report on International Religious Freedom for 2006 - Macedonia, https://www.refworld.org/country,,,,MKD,,45 ofbob720,o.html (date of last access: 16.09.2020).

US Department of State: 2019 Country Reports on Human Rights Practices: North Macedonia, https://www.state.gov/reports/2019-country-reports-on-human-rightspractices/north-macedonia/ (date of last access: 11.09.2020).

Vankovska, Biljana: A Diplomatic Fairytale or Geopolitics as Usual: a Critical Perspective of the Agreement between Athens and Skopje, OSCE Yearbook 2018, https://www. researchgate.net/publication/337731982_A_Diplomatic_Fairytale_or_Geopolitics_ as_Usual_A_Critical_Perspective_on_the_Agreement_between_Athens_and_ Skopje, June 2019 (date of last access: 11.09.2020).

Velevski, Marjan:Interview with James Pettifer, in: Nova Makedonija, https://www.novamakedonija.com.mk/makedonija/македонија-се-става-во-вазалска-полож, published on 07.07 .2018 (date of last access: 11.09.2020). 
Waters, Adrian: The Truth about the Prespa Agreement, Institute for a Greater Europe, https://www.institutegreatereurope.com/single-post/2019/o1/11/The-Truth-abou t-the-Prespa-Agreement, published on 11.02.2019 (date of last access: 11.09.2020).

WIN-Gallup International: Global Index of Religion and Atheism, https://sidmennt.is/ wp-content/uploads/Gallup-International-um-trú-og-trúleysi-2012.pdf (date of last access: 11.09.2020).

World Council of Churches: Round Table Meeting with religious communities of the Republic of Macedonia. La Longeraie, Morges, Switzerland, 11-13 June 2001, http://www.wcc-coe.org/wcc/news/press/o1/macedonia.html (date of last access: 21.09.2O2O).

World Jewish Restitution Organization: WJRO North Macedonia Operations, https:// wjro.org.il/our-work/restitution-by-country/macedonia/ (date of last access: 11.09.2020).

Zaloga, Steven/Volstad, Ronald: The Yugoslav Wars, Bosnia, Kosovo And Macedonia 1992-2001, Vol. 2. Oxford: Oxford University Press, 2006. 